\title{
Pemberdayaan pada Kelompok Remaja melalui Pendekatan Contingency Planning dalam Meningkatkan Kesiapsiagaan terhadap Ancaman Kematian Akibat Bencana
}

\author{
Sehabudin Salasa $^{1}$, Tri Wahyu Murni ${ }^{2}$, Etika Emaliyawati $^{3}$ \\ 1,2,3 Prodi Magister Keperawatan Peminatan Keperawatan Kritis UNPAD \\ Email: ${ }^{1}$ Sehabudinsa188@gmail.com
}

\begin{abstract}
ABSTRAK
Angka kematian kelompok rentan akibat bencana masih sangat tinggi, seperti kejadian banjir bandang Garut dari 34 orang korban jiwa 35,4\% diantaranya berusia 55-80 tahun dan 29\% merupakan anakanak usia 0-14 tahun. Upaya pengurangan resiko harus dilakukan dengan memberdayakan masyarakat sehingga proses penanggulangan lebih efektif dengan respon yang cepat. Usia remaja merupakan kelompok yang sangat potensial karena memiliki angka resiliensi yang sangat baik. Selain itu pertumbuhan jumlah remaja sangat pesat dari kelompok umur lainnya, sehingga pemberdayaan kelompok remaja dengan perencanaan kontinjensi diharapkan meningkatkan kesiapsiagaan terhadap ancaman kematian sehingga dapat melakukan pendampingan terhadap kelompok rentan. Penelitian ini bertujuan mengetahui pengaruh pemberdayaan (empowering) kelompok remaja akhir melalui pendekatan perencanaan kontinjensi dalam meningkatkan kesiapsiagaan remaja terhadap ancaman kematian akibat bencana. Penelitian menggunakan metoda quasi-experimental design dengan pendekatan rancangan one group pre-post test design. Populasi penelitian merupakan pelajar SMK diwilayah yang memiliki ancaman bencana. Jumlah sampel sebanyak 33 responden dengan teknik proporsional random sampling diambil dari empat sekolah yang berada di zona merah. Data diolah menggunakan analisis univariat menggunakan tendensi sentral, t-test dependent dengan tingkat kepercayaan 95\% untuk melihat pengaruh dari intervensi, serta uji regresi linier ganda untuk menganalisis faktor mana yang paling berpengaruh terhadap kesiapsiagaan.Terdapat pengaruh pemberdayaan melalui pendekatan perencanaan kontinjensi dapat meningkatkan upaya kesiapsiagaan dengan nilai $\alpha(0.000)$. Peningkatan rerata $(36,67 \%)$ didapatkan pada faktor yang mengawali kesiapsiagaan, diantaranya dilihat dari persepsi terhadap resiko, kewaspadaan terhadap ancaman, serta penurunan kecemasan. Faktor tersebut menstimulasi terbentuknya niat melakukan kesiapsiagaan dengan peningkatan $(43,33 \%)$, bahkan meningkatkan upaya perencanaan kesiapsiagaan bencana sebesar $(42,00 \%)$ sebelum dan setelah intervensi. Ketiga faktor tersebut saling berkaitan dan faktor pembentukan niat melakukan kesiapsiagaan menjadi faktor yang sangat berpengaruh terhadap kesiapsiagaan dengan nilai $\beta(0,531)$. Hasil penelitian menunjukkan bahwa proses pemberdayaan melalui pendekatan perencanaan kontinjensi mampu meningkatkan kesiapsiagaan remaja terhadap ancaman kematian akibat bencana, sehingga dapat direkomendasikan bagi seluruh penggiat kebencanaan untuk memberdayakan remaja dengan perencanaan kontinjensi dalam upaya meningkatkan kesiapsiagaan terhadap ancaman kematian.
\end{abstract}

Kata kunci: kesiapsiagaan remaja, perencanaan kontinjensi, kesiapsiagaan bencana

\section{ABSTRACT}

The mortality rate of vulnerable groups due to the disaster is still very high, such as the incidence of flash floods at Garut, of the 34 deaths among them $35.4 \%$ are $55-80$ years old and $29 \%$ of children aged 0-14 years. Risk reduction efforts should be undertaken by empowering communities so that the countermeasures are more effective with rapid response. Adolescence is very potent because it has a very good resilience rate. In addition, the growth of adolescents is very rapidly from other age groups, so empowerment of adolescent groups with contingency planning is expected to increase preparedness 
against death threats so as to provide assistance to vulnerable groups. The purpose of this study was to determine the influence of empowering the late adolescent group through contingency planning approach in the effort of preparedness against the threat of death due to the disaster. This study used quasi-experimental design method with one group pre-post test design approach. The study population was a vocational school student in the region that has disaster threats. The number of samples was 33 respondents with proportional random sampling technique from 4 schools in the red zone. Data were tested for data were analyzed by a central tendency for univariate analysis, t-test dependent with 95\% confidence level to see the effect of the intervention, and determination of the most influential factor, the researcher used multiple linear regression tests. Results of the study showed there is the influence of empowerment through contingency planning approach can improve preparedness efforts with $\alpha$ value (0.000). Percentages before and after the intervention can significantly improve the precursor factor increase $(36.67 \%)$, intention formation (43.33\%), and preparation (42.00\%). In addition, intention formation factor is the most influential factor in preparedness efforts with $\beta$ value $(0,531)$. This study concluded that the empowerment through contingency planning approach can improve preparedness efforts of adolescence group to the threat of death from disaster. So it is recommended for all disaster activists to empower adolescents with contingency planning in an effort to increase preparedness against death threats

Keywords: adolescent preparedness, contingency planning, disaster preparedness

\section{PENDAHULUAN}

Angka kejadian bencana di Indonesia sangat memprihatinkan, berdasarkan data dari Pusat Penanggulangan Krisis (PPK) Kesehatan Kementerian Kesehatan dalam rentang waktu (2010-2012) mencatat sekitar 1015 kejadian bencana yang menyebabkan krisis kesehatan, atau rata-rata 338 kali pertahun, maka dapat dikatakan bahwa setiap hari terjadi bencana di Indonesia (PPKKemenkes, 2013). Sejalan dengan data tersebut, Badan Nasional Penanggulangan Bencana (BNPB) mencatat delapan Provinsi yang paling sering dilanda bencana selama periode 2016. Provinsi Jawa Barat menempati peringkat ketiga setelah Jawa Tengah dan Jawa Timur (BNPB, 2016). Terdapat lima daerah di Jawa Barat yang termasuk sepuluh kabupaten atau kota paling rawan terjadi bencana, salah satunya adalah Kabupaten Garut (BPBD-Jabar, 2011).

Kejadian banjir bandang di Kabupaten Garut pada tanggal 20 september 2016 luput dari perhatian kajian resiko. Akibat kejadian tersebut, 34 orang korban meninggal, 35 lukaluka, 1326 pengungsi dan 19 orang hilang. Dari data korban meninggal diantaranya $35,4 \%$ berusia $55-80$ tahun dan $29 \%$ usia anak-anak 0-14 tahun (BPBD-Jabar, 2016).
Badan Penanggulangan Bencana Daerah (BPBD) Provinsi Jawa Barat telah melakukan proses pembinaan dan pelatihan berbasis relawan di masyarakat baik pada fase pra, intra, atau pasca bencana, akan tetapi lebih sering bersifat internal kepada relawan BPB (BPBD-Jabar, 2016). Sementara itu, program yang ditujukan bagi masyarakat masih terkesan berjalan satu arah yaitu dari pihak pemerintah terhadap masyarakat. Hasil observasi didapatkan di lingkungan sekolah di kecamatan samarang masih minimnya saran jalur evakuasi, sistem peringatan dini, serta sarana belajar mengajar penanggulangan bencana. Berbagai upaya tersebut masih terdapat masalah utama yang ada dimasyarakat diantaranya: masih rendahnya kinerja penanggulangan bencana, rendahnya perhatian perlunya pengurangan resiko bencana, dan masih lemahnya peran sekolah dalam pendidikan mitigasi bencana (Astuti \& Sudaryono, 2010). Sejalan dengan hal tersebut peningkatan kapasitas masyarakat khususnya dalam penanggulangan bencana serta kasus-kasus kegawatdaruratan yang disebabkan bencana masih belum memiliki panduan yang baku, sehingga upaya yang dilakukan belum efektif untuk menyadarkan masyarakat bahwa mereka merupakan ujung 
tombak dalam penanggulangan bencana yang seharusnya bersifat proaktif.

Merujuk hal tersebut dibutuhkan suatu upaya pendekatan untuk merubah cara pandang dari masyarakat yang menegaskan bahwa upaya-upaya penanggulangan bencana merupakan kebutuhan dari setiap individu. Selain itu, paradigma masyarakat korban bencana yang berada di tempat pengungsian umumnya akan merasa dirinya sebagai korban yang perlu ditolong, sehingga diperlukan dorongan atau motivasi yang kuat dari petugas kesehatan untuk meyakinkan masyarakat dapat menolong dirinya sendiri terutama dalam upaya peningkatan kesehatan dan mencegah ancaman kematian (Indriyati \& Antaria. 2013).

Program PRBOM tersebut dapat diintegrasikan khususnya di bidang kesehatan dan kegawatdaruratan karena sejalan dengan peran dan fungsi perawat, khususnya perawat yang berkecimpung dengan masalah kegawatdaruratan dan bencana. Menurut American association of critical care nurses (AACN) tahun 2015 lingkup praktik keperawatan kritis terbagi menjadi penanganan akut dan kronis. Penanganan pasien pada fase akut dapat terjadi pada lingkup pra Rumah Sakit. Bahkan pada beberapa kejadian kematian korban diakibatkan kesalahan dan keterlambatan dalam pertolongan pertama sebelum dibawa ke Rumah Sakit (U.S. Departement of Health and Human Sevices, 2011).

Upaya yang dapat dilakukan untuk menjawab permasalahan ini khususnya dalam konteks kegawatdaruratan dan bencana, perawat perlu mengoptimalkan peran fundamental dari masyarakat dimana masyarakat dapat selain dapat menyelamatkan dirinya sendiri juga dapat di berdayakan sebagai first aider (U.S. Departement of Health and Human Sevices. 2011). Upaya optimalisasi peran masyarakat tersebut diawali dengan memberdayakan kelompok masyarakat dalam setiap fase bencana khususnya pra-bencana sehingga akan terbentuk kelompok masyarakat yang siap siaga.

Kesiapsiagaan merupakan serangkaian kegiatan yang dilakukan untuk mengantisipasi bencana melalui pengorganisasian serta melalui langkah yang tepat guna dan berdaya guna (UU RI No.24 Tahun 2007). Menurut LIPI UNESCO/ISDR (2006) dalam Dodon (2016) salah satu indikator kesiapsiagaan individu dan rumah tangga terhadap bencana alam adalah pengetahuan dan sikap terhadap resiko bencana. Hal tersebut sejalan dengan risk perception and preparedness model (Paton, 2007) yang mengemukakan tiga aspek yang berpengaruh untuk menciptakan budaya kesiapsiagaan pada masyarakat. Aspek tersebut diantaranya: faktor prekursor, intention formation, dan preparation planing. Faktor prekursor ditunjang oleh risk perception, critical awareness dan anxiety. Risk perception merupakan hasil internalisasi dari informasi mengenai ancaman dan bahaya yang mungkin diakibatkan oleh bencana, sedangkan critical awareness merupakan kewaspadaan yang muncul terhadap ancaman yang dipersepsikan ditandai dengan seberapa sering individu tersebut berupaya dan memikirkan dampak dari bencana. Kedua sub variabel tadi menunjang dalam mengurangi kecemasan (anxiety) pada suatu individu (Paton et. al. 2005).

Upaya dalam meningkatkan kesadaran individu atau masyarakat tersebut dilakukan dengan proses pemberdayaan melalui pendekatan perencanaan kontinjensi dengan melihat faktor-faktor prekursor, intention formation, dan preparation planing (Paton. 2007). Menurut IASC dalam Vidiarina (2010) perencanaan kontinjensi merupakan proses membentuk tujuan, pendekatan, dan prosedur program untuk menanggapi situasi atau kejadian yang cenderung terjadi. Perencanaan tersebut meliputi upaya mengidentifikasi kejadian serta mengembangkan skenario yang mungkin dan rencana yang patut untuk menyiapkan diri terhadap dan menanggapi kejadian itu secara efektif. Perencanaan 
kontinjensi yang dilakukan tidak terlepas pada empat tahapan yang di kemukakan oleh Inter-Agency Standing Committee (IASC) dalam Vidiarina (2010), diantaranya: mempersiapkan dan menyelenggarakan proses perencanaan kontinjensi, melakukan analisis bahaya dan risiko, pengembangan skenario, menentukan tujuan dan strategi tanggap darurat, serta melakukan upaya kesiapsiagaan. Melalui pendekatan tersebut seluruh komponen masyarakat dapat disadarkan dan dilibatkan mengenai upaya kesiapsiagaan bencana terutama kelompok remaja, karena menurut sensus penduduk tahun 2010 usia remaja (10-19 tahun) diperkirakan sebanyak 43,5 juta atau sekitar $18 \%$ dari seluruh jumlah penduduk (WHO, 2014 dalam Pusat Data dan InformasiKemenkes RI, 2015).

Ditinjau dari sisi perkembangan, usia remaja memiliki potensi yang tinggi khusunya pencapaian perkembangan yang pesat pada kemampuan berpikir dan pergeseran mengenai peran baru di masyarakat. Selain itu, dikatakan pula bahwa kelompok usia remaja memiliki angka resiliensi yang baik pasca bencana tsunami Aceh tahun 2004 (Oktaviani, 2012)

Berangkat dari pemikiran tersebut, melihat karakteristik remaja yang begitu kuat diharapkan dapat memiliki kesadaran yang baik untuk melakukan kesiapsiagaan terhadap ancaman kematian akibat bencana. Oleh karena itu peningkatan kesiapsiagaan dengan cara mengkonstruksi faktor prekursor, intention formation, dan preparation planning penting dilakukan. Hal tersebut dilakukan untuk menumbuhkan sikap proaktif dari individu atau masyarakat dalam penanggulangan bencana, selain itu diharapkan dapat menstimulasi kegiatan kesiapsiagaan yang berlangsung secara terus menerus. Dengan cara tersebut maka permasalahan yang selama ini timbul seperti tingginya ancaman kematian, program peningkatan kapasitas yang berlangsung satu arah dari pemerintah, serta tidak dipeliharanya pengetahuan dan kemampuan masyarakat yang telah terpapar penanggulangan bencana dapat terpecahkan oleh kesiapsiagaan yang dimiliki individu atau masyarakat tersebut, karena mereka telah memiliki kesadaran sendiri. Selain itu hasil penelitian Paton (2007) yang menyatakan bahwa individu yang memiliki pengalaman terdampak bencana memiliki kesiapsiagaan yang baik, dapat diiimbangi oleh kelompok yang belum memiliki pengalaman terdampak bencana tanpa harus menunggu bencana itu terjadi.

Atas dasar data dan fakta diatas maka penyusun berpikir bahwa perlunya kajian mengenai pengaruh pemberdayaan (empowering) pada remaja akhir melalui pendekatan perencanaan kontinjensi dalam meningkatkan kesiapsiagaan remaja terhadap ancaman kematian akibat bencana di Kabupaten Garut. Tempat penelitian dilakukan di SMA/SMK sederajat dari dua Kecamatan yaitu Kecamatan Bayongbong dan Kecamatan Samarang sesuai uraian diatas bahwa kedua Kecamatan tersebut termasuk pada wilayah rawan atau zona merah. Selain itu di daerah tersebut memiliki keterwakilan dampak bencana lebih dari satu jenis bencana.

\section{METODE}

Desain penelitian yang digunakan pada penelitian ini adalah penelitian kuantitatif menggunakan metoda quasi-experimental design dengan pendekatan rancangan one group pre-post test design (Sugiyono. 2010). Penelitian ini membandingkan upaya kesiapsiagaan remaja akhir terhadap ancaman kematian akibat bencana sebelum dan sesudah melakukan intervensi, dengan indikator faktor prekusor (risk perception, critical awarenes, dan anxiety) dan intention formation (self efficacy, outcome expectancy, dan active coping), serta preparation planing.

\section{Populasi dan Sampel}

Populasi pada penelitian ini adalah pelajar SMA/SMK sederajat dengan rentang 
usia (16-19 tahun) yang terletak di daerah rawan bencana yaitu di Kecamatan Bayongbong dan Kecamatan Samarang. Penentuan jumlah sampel peneliti mengambil jumlah sampel minimal menurut Baley dalam Mahmud (2011) bahwa untuk penelitian yang menggunakan analisis data statistik, ukuran sampel paling minimum adalah 30 , ditambah kemungkinan untuk drop out $15 \%$ sehingga menjadi 35 orang. Pengambilan sampel menggunakan probability sampling dengan teknik proporsional random sampling. Pengambilan unit populasi didapatkan empat sekolah SMA/SMK sederajat yang berada di zona merah di Kecamatan tersebut diantaranya, SMK Al-Istiqomah, SMK Plus Qurota'ayun, SMK Plus Al-amin dan SMK Mutiara Bangsa. Penetapan jumlah sampel dari setiap unit populasi diatas dilakukan dengan memberikan proporsi $25 \%$ dari jumlah total sampel yang dibutuhkan, sehingga setiap sekolah mengirimkan 9-10 orang siswanya yang memenuhi kriteria untuk mengikuti penelitian ini.

\section{Pengumpulan data}

Instrumen ini berisikan lembar soal pertanyaan dan pernyataan sederhana yang harus dijawab atau diisi tentang berbagai hal terkait kebencanaan. Menyangkut faktor prekusor (risk perception, critical awareness, dan anxiety), intention formation (self efficacy, outcome expectancy, active coping), serta perencanaan upaya kesiapsiagaan. Seluruh komponen pernyataan atau pertanyaan menggunakan skala likert 1-4 dengan jumlah total item pernyataan dan pernyataan 40. Hasil uji validitas didapatkan rentang hitung berkisar antara 0,363 sampai 0,799 , serta nilai reabilitas crobach's alfa 0,741 .

Pengumpulan data dilakukan dengan 2 tahap diantaranya tahap pengambilan data pre test kemudian post test yang sebelumnya responden informed concent. Pengumpulan data dilakukan dengan cara membagikan kuesioner terhadap seluruh peserta setelah diberikan penjelasan mengenai tatacara pengisian kuesioner tersebut, selain itu peserta terbagi beberapa kelompok yang didampingi fasilitator dalam melakukan pengisian kuesioner tersebut. Setelah dilakukan pengumpulan data pre test responden di berikan intervensi dengan pelatihan menggunakan pendekatan perencanaan kontinjensi yang terdiri: mempersiapkan dan menyelenggarakan proses perencanaan kontinjensi, analisis bahaya dan risiko, pengembangan skenario dan pengembangan asumsi perencanaan, perencanaan tanggap darurat, diantaranya: menentukan tujuan dan strategi tanggap darurat, menentukan pengaturan manajemen dan koordinasi untuk tanggap kemanusiaan, mengembangkan rencana tanggapan, serta melakukan upaya kesiapsiagaan. untuk dapat menerapkan langkah-langkah intervensi sesuai dengan perencanaan kontinjensi dalam pelaksanaannya terbagi 3 bagian, diantaranya: Bagian 1 (Introducing dan exploring), Bagian II (penguatan, Application, dan reflection), dan bagian III (lanjutan).

\section{Analisa Data}

Analisis data dalam penelitian ini terdiri dari analisis univariat, bivariat multivariat. Analisis data univariat menggunakan nilai presentase untuk hasil yang didapatkan dari setiap variabel yang teliti. Selain itu analisis data bivariat menggunakan t-test dependent untuk mengetahui pengaruh dari intervensi yang dilakukan terhadap kesiapsiagaan remaja terhadap ancaman kematian akibat bencana dengan melihat nilai $\alpha$. Sedangkan analisis data multivariat menggunakan analisis linier ganda untuk melihat keterkaitan antar ke 3 sub variabel serta untuk melihat sub variabel mana yang sangat berpengaruh dalam mengkonstruksi kesiapsiagaan remaja terhadap ancaman kematian akibat bencana. 


\section{HASIL}

Tabel 1. Karakteristik responden

\begin{tabular}{llcc}
\hline Karakteristik & Kategori & Jumlah $(\boldsymbol{\Sigma})$ & Persentase (\%) \\
\hline Usia & 16 Tahun & 14 & 42,40 \\
& 17 Tahun & 16 & 48,50 \\
& 18 Tahun & 3 & 9,10 \\
& 19 Tahun & 0 & 0 \\
& & & 27,30 \\
\hline Pengalaman terhadap bencana & Memiliki pengalaman & 9 & 72,7 \\
& Tidak memiliki pengalaman & 24 & 100.00 \\
& & & 0 \\
\hline Lama tinggal di Kota/ Kabupaten & $>5$ tahun & 33 & 6,10 \\
& $1-5$ tahun & 0 & 93.90 \\
\hline Lama tinggal di rumah atau & $>5$ tahun & 2 & 31 \\
lingkungan yang ditempati & $1-5$ tahun & & \\
\hline
\end{tabular}

Tabel 2. Karakteristik Upaya Kesiapsiagaan Sebelum dan Sesudah Intervensi

\begin{tabular}{ccccccc}
\hline $\begin{array}{c}\text { Upaya } \\
\text { Kesiapsiagaan }\end{array}$ & \multicolumn{2}{c}{ Belum Siap (Skor 40-80) } & \multicolumn{2}{c}{ Kurang Siap (Skor 81-120) } & \multicolumn{2}{c}{ Siap (Skor 121-160) } \\
\cline { 2 - 7 } & $\begin{array}{c}\text { Frekuensi } \\
\text { (f) }\end{array}$ & $\begin{array}{c}\text { Persentase } \\
(\%)\end{array}$ & $\begin{array}{c}\text { Frekuensi } \\
\text { (f) }\end{array}$ & $\begin{array}{c}\text { Persentase } \\
(\mathbf{\%})\end{array}$ & $\begin{array}{c}\text { Frekuensi } \\
(\mathbf{f})\end{array}$ & $\begin{array}{c}\text { Persentase } \\
(\%)\end{array}$ \\
\hline Sebelum Intervensi & 0 & 0 & 21 & 63,60 & 12 & 36,40 \\
Setelah Intervensi & 0 & 0 & 2 & 6,10 & 31 & 93,90 \\
\hline
\end{tabular}

Tabel 3. Perbedaan rerata upaya kesiapsiagaan sebelum dan setelah dilakukan intervensi

\begin{tabular}{lllll}
\hline Variabel & Kelompok & Rerata & SD & P \\
\hline \multirow{2}{*}{ Upaya Kesiapsiagaan } & Sebelum & 117,55 & 10,563 & 0.000 \\
& Sesudah & 132,76 & 10,753 & \\
\hline
\end{tabular}

*t-test dependent

Tabel 4. Hubungan antara faktor-faktor upaya kesiapsiagaan

\begin{tabular}{lccc}
\hline Variabel & Faktor Prekursor & Intention Formation & Preparation Planing \\
\hline Faktor Prekursor & - & 0,040 & 0.006 \\
Intention Formation & 0,040 & - & 0.000 \\
Preparation Planing & 0,006 & 0,000 & - \\
\hline
\end{tabular}

Tabel 5. Analisa faktor-faktor yang mendominasi upaya kesiapsiagaan

\begin{tabular}{lccc}
\hline Variabel & Std Error & $\beta$ & Sig \\
\hline Faktor Prekursor & - & - & - \\
Intention Formation & 0,173 & 0,531 & 0.000 \\
Preparation Planing & 0,259 & 0,496 & 0.000 \\
\hline
\end{tabular}

\section{Analisis bivariat}

Pada tabel diatas menunjukan bahwa upaya kesiapsiagaan pada responden sebelum dilakukan intervensi memiliki rerata $(117,55)$ lebih rendah jika dibandingkan setelah dialkukan intervensi yaitu (132,76). Hal tersebut menunjukan terdapat perbedaan signifikan antara upaya kesiapsiagaan responden sebelum dan setelah diberikan intervensi dengan $\mathrm{p}$ value $=0,000$.

\section{Analisis multivariat}

Berdasarkan tabel 4 Hubungan faktor prekursor terhadap intention formation menghasilkan $\mathrm{p}$ value $(0,40)$, hubungan faktor prekursor terhadap preparation planing 
menghasilkan $\mathrm{p}$ value $(0,006)$, dan intention formation terhadap preparation planing menghasilkan $\mathrm{p}$ value $(0,000)$.

\begin{abstract}
Berdasarkan tabel 5, hubungan faktor yang dominan memengaruhi upaya kesiapsiagaan adalah intention formation dengan nilai $\beta(0,531)$, diikuti faktor preparation planing $\beta(0,496)$, sedangkan faktor prekursor tidak memiliki pengaruh terhadap upaya kesiapsiagaan hal tersebut ditunjukan bahwa faktor tersebut terdegradasi pada tahapan uji regresi linier ganda karena nilai uji t-test independen menghasilkan $p$ value $(0,546)$.
\end{abstract}

\section{PEMBAHASAN}

Penelitian ini bertujuan untuk melihat bagaimana suatu pemberdayaan kelompok remaja akhir melalui sebuah pendekatan perencanaan kontinjensi memiliki pengaruh terhadap peningkatan kesiapsiagaan atau tidak. Kesiapsiagaan yang dimaksudkan dalam penelitian ini merupakan sebuah interaksi dari proses pikir, keyakinan akan kemampuan seseorang sampai mereka memiliki upaya tindakan antisipasi jika hal terburuk akibat bencana terjadi. Hal tersebut lebih dikenal dengan preparednes model yang dikemukakan oleh Paton et. al (2005). Penerapan model tersebut terbagi menjadi tiga faktor yang saling keterkaitan diataranya faktor prekursor, intention formation, dan preparation planning. Ketiga segmen tersebut saling berkaitan dalam menciptakan perilaku kesiapsiagaan (Paton. 2007).

Hasil penelitian ini menunjukan bahwa kesiapsiagaan responden sebelum dilakukan intervensi berada pada kategori kurang siap yaitu sejumlah 21 orang $(63,60 \%)$, bahkan ada yang sudah berada pada kategori siap yaitu sebanyak 12 orang $(36,40 \%)$. Hal tersebut dapat disebabkan oleh faktor-faktor eksternal salah satunya faktor lingkungan. Kelompok remaja akhir yang menjadi responden pada penelitian ini berada pada lingkungan yang rawan terhadap kejadian bencana, sehingga secara tidak langsung dapat memengaruhi upaya kesiapsiagaannya (Raharjo. 2010). Hal tersebut sejalan dengan teori model social cognitive yang dikemukakan oleh Badura (1986) dalam Grizzell (2007) bahwa antara perilaku, lingkungan dan faktor internal dari individu masing-masing memiliki interaksi dalam mengonstruksi pengetahuan dan sikap masing-masing. Selain hal tersebut upaya kesiapsiagaan remaja akhir yang menjadi responden dipengaruhi oleh lamanya waktu tinggal di lingkungan tersebut. Menurut hasil penelitian didapatkan bahwa responden hampir seluruhnya bertempat tinggal diwilayah tersebut lebih dari lima tahun yaitu 31 orang $(93,90 \%)$ sehingga responden dapat dikatakan sudah sangat mengenal daerah mereka masing-masing.

Atas dasar data diatas maka wajar jika kondisi kesiapsiagaan remaja yang menjadi responden berada pada level kurang siap dikarenakan pengaruh lingkungan. Faktor lingkungan tersebut berpengaruh karena remaja yang diambil menjadi responden merupakan remaja yang bertempat tinggal dikawasan rawan bencana, sehingga secara kehidupan sosial mereka mungkin pernah diperlihatkan dengan budaya lokal dalam menanggulangi atau mencegah bencana. Meskipun secara umum responden yang menyatakan diri memiliki pengalaman dalam penanggulangan bencana baik pengalaman belajar, pengalaman menjadi korban, ataupun pengalaman melakukan pertolongan hanya berjumlah sembilan orang $(27,30 \%)$, akan tetapi orang yang hidup didaerah rawan bencana meskipun belum memiliki pengalaman secara langsung, belum tentu tidak memiliki upaya kesiapsiagaan.

Berdasarkan data, level kurang siap merupakan suatu kategori dimana remaja telah memiliki respon untuk melakukan kesiapsiagaan akan tetapi belum memadai atau maksimal, sehingga dapat dikatakan jika seorang individu yang tinggal didaerah rawan bencana memungkinkan mereka telah 
memiliki langkah-langkah antisipatif. Akan tetapi untuk mengefektifkan langkah antisipatif tersebut perlu penyamaan persepsi agar sistem penanggulangan bencana dapat berjalan sesuai dengan harapan. Untuk menyamakan persepsi tersebut diperlukan pendekatan perencanaan kontinjensi dapat membangun kesadaran individu terhadap ancaman sesuai dengan karakteristik daerahnya masing masing.hal ini sejalan dengan teori Paton et.al. (2005) mengenai elemen-elemen yang dapat menimbulkannya suatu perilaku kesiapsiagaan dimana elemen terpenting diantaranya yaitu mengokohkan faktor prekursor yang terdiri dari critical awareness dan risk perception. Sedangkan konsep pemberdayaan dikatakan dapat mengasah intuisi peserta atau remaja dalam mengeksplorasi langkah-langkah kesiapsiagaan sesuai dengan yang dikatakan Dodon (2013) dalam kesiapsiagaan banjir, begitupun hasil penelitian Indriyati \& Antaria (2013) dan pencegahan kejadian luar biasa (KLB) di pengungsian.

Hasil penelitian menunjukan bahwa pemberdayaan melalui pendekatan perencanaan kontinjensi sangat berpengaruh terhadap upaya kesiapsiagaan remaja akhir terhadap ancaman kematian akibat bencana. hal tersebut di tunjukan dengan hasil $p$ value $=0,000$ yang menandakan adanya kaitan yang erat. Dengan rerata sebelum intervensi berada pada kisaran 117,55 meningkat setelah dilakukan intervensi menjadi 132,76. Sedangkan standar deviasi sebelum berkisar 10,563 dan setelah intervensi menjadi 10,75 hal ini menunjukan sebaran data setelah intervensi lebih beragam.

Faktor-faktor yang dapat memengaruhi upaya kesiapsiagaan remaja akhir tersebut adalah pengalaman mereka mengenai kebencanaan. Hasil penelitian didapatkan sembilan orang responden memiliki pengalaman beragam mengenai kebencanaan. Beberapa diantaranya memiliki pengalaman pernah menjadi korban bencana secara langsung atau tidak langsung, adapula yang memiliki hanya pengalaman belajar tentang bencana, bahkan pengalaman menolong korban bencana. Dalam Paton et. al. (2005) dikatakan pengalaman dalam bentuk apapun terlebih pengalaman bencana secara langsung dapat menstimulasi persepsi seseorang terhadap bencana. Akan tetapi persepsi tersebut bisa negatif maupun positif. Persepsi yang positif ini sangat menunjang terhadap pembentukan niat dalam diri individu untuk melakukan upaya-upaya kesiapsiagaan.

Menurut Raharjo (2010) persepsi publik tentang bencana memegang peranan penting dalam penanganan bencana. Karakter publik seperti rasional, tradisional, individualis, maupun kolektif turut memengaruhi kebijakan negara terhadap bencana. Sejalan dengan hal tersebut Grizzell (2007) dalam teori planned behaviour dikatakan bahwa persepsi dapat memengaruhi kontrol terhadap perilaku yang nantinya akan mengubah norma secara subjektif terhadap suatu masalah, sehingga akan menstimulasi niat atau upaya untuk melakukan sesuatu sehingga menjadi kebiasaan atau budaya baru. Selain itu kesiapsiagaan remaja juga dapat dipengaruhi oleh dukungan lingkungan keluarga agar perilaku remaja dapat beradaptasi dengan perubahan ideal dirinya masing-masing selama dalam masa pubertas (Triyanto,Setiyani, dan Wulansari, 2016).

Penelitian mengenai kesiapsiagaan yang dilakukan oleh firmansyah, Rasni, dan Rondhianto (2014) menunjukan adanya hubungan antara pengetahuan terhadap perilaku kesiapsiagaan pada usia remaja. Begitu juga penelitian yang dilakukan oleh Martin, Martin, dan Kent (2009) tentang role of risk perception in the risk mitigation process didapatkan hasil bahwa secara subjektif pengetahuan tentang bencana dapat memengaruhi tanggung jawab individu terhadap upaya pengurang resiko bencana, selain itu faktor yang paling berpengaruh dalam mengubah perilaku pengurang resiko bencana pada individu tersebut adalah persepsi individu terhadap ancaman atau 
resiko (risk perception) terhadap bencana. Begitu pun Paton et. al. (2005) membahas mengenai keterkaitan hal ini melalui teori Preparednes Model yang diadaptasi dari Paton et. al (2005) dalam Patton (2007). Dari beberapa penelitian tersebut dapat dijadikan landasan bahwa dalam meningkatkan kapasitas individu terhadap penanggulangan bencana perlu diperhatikan faktor elementer yaitu risk perception.

Meskipun faktor-faktor tersebut saling memengaruhi akantetapi perlu pendekatan yang efektif khususnya untuk mengubah elemen-elemen dasar seperti yang dikemukakan hasil penelitian diatas. Elemenelemen dasar tersebut diantaranya pengetahuan dan risk perception. Metode pendekatan tersebut perlu dikarenakan bahwa setiap individu memiliki dasar pengetahuan dan persepsi yang berbeda-beda mengenai resiko bencana, terlebih jika dilihat dari faktor-faktor yang dijelaskan diatas seperti pengalaman dan lama tinggal didaerah yang mereka huni saat ini. Oleh karena itu upaya menyeragamkan dan mengkonstruksi pemahaman serta persepsi individu terhadap bencana sangatlah penting, agar setiap individu dapat memiliki output yang sama dalam upaya kesiapsiagaan yang timbul dari dirinya sendiri dengan baik dan berkelanjutan (Paton, 2007). Selain itu kelompok individu tersebut dapat menjadi agen pembaharu dimasyarakat bahkan dapat memiliki kesadaran dalam menjadi first responder terhadap ancama kematian yang mungkin ditimbulkan oleh bencana (U.S. Departement of Health and Human Sevices. 2011).

Upaya memaksimalkan peran remaja akhir dalam penanggulangan bencana masih belum dimaksimalkan dengan baik. Oleh karena itu pemerintah memiliki program pemberdayaan yang memiliki prinsip utama penyadaran masyarakat akan ancaman kematian akibat bencana (PPK-Kesehatan, 2015). Program tersebut memiliki dua domain yakni peningkatan kapasitas melalui pendidikan dan pelatihan serta program pembinaan berkelanjutan. Dalam penelitian ini fokus telaahan pada remaja akhir yang sangat potensial baik dari segi perkembangan secara emosional yang menunjukkan berkembangnya kemampuan berpikir dan pergeseran mengenai peran baru di masyarakat (Oktaviani. 2012). Selain itu, dikatakan bahwa kelompok usia remaja memiliki angka resiliensi yang baik pasca bencana tsunami Aceh tahun 2004 (Oktaviani. 2012). Sejalan dengan hal tersebut Bronfenbrenner dalam Zuldafrial (2010) menyediakan sebuah model ekologis dalam memahami perkembangan manusia yang menyatakan perkembangan anak dan remaja paling banyak di konstruksi dalam kontek keluarga, setting pendidikan dan komunitas.

Upaya pemberdayaan yang dilakukan untuk menstimulasi pola pikir remaja dalam penanggulangan bencana yang berkelanjutan yaitu dengan merubah, mendorong dan meningkatkan persepsi remaja terhadap faktor resiko yang mungkin timbul akibat bencana. proses pemberdayaan dalam upaya peningkatan kapasitas individu terhadap ancaman kematian akibat bencana dapat dilakukan dengan pendidikan formal maupun pendidikan informal seperti pelatihan (Muttarak \& Pothisiri, 2012). Terlebih remaja yang tergolong masih dalam masa pendidikan menengah, sehingga penerapan program pemberdayaan ini dapat dilakukan secara berkelanjutan baik masuk ke dalam mata ajar ataupun muatan lokal. Selain itu karakteristik remaja yang memiliki nilai resiliensi yang baik pada saat tsunami Aceh menurut Oktaviani (2012) dapat menunjang kelompok usia remaja ini dapat melakukan proses kesiapsiagaan yang efektif bahkan dapat melakukan proses pendampingan terhadap kelompok rentan yang ada diwilayahnya.

Pendidikan kebencanaan merupakan langkah strategis dalam meningkatkan kesiapsiagaan serta sebagai bentuk pemberdayaan masyarakat dalam mengurangi resiko bencana (Kanage dan Adiyoso, 2012; Izadkhah, 2008). Dalam kenyataannya belum semua sekolah yang memberikan perhatian 
yang sama pentingnya dalam menerapkan pendidikan kebencaan di Indonesia. Hal tersebut terbukti sejumlah 71 sekolah yang tersebar di Banda Aceh dan Aceh jaya tidak menggunakan kurikulum dalam memberikan pendidikan bencana (Kanage dan Adiyoso, 2012). Bahkan pendidikan bencana yang terjadi di Indonesia lebih bersifat pelatihan yang insidental tidak berkelanjutan. Dalam rangka uji coba kurikulum kebencanaan yang dilakukan oleh Subagja, didapatkan hasil Penerapan kurikulum mitigasi bencana alam gempa bumi (MBAGB) belum dapat menunjukan peningkatan yang signifikan terhadap pengetahuan dan kemampuan (Wiratma \& Sudita, 2015).

Terdapat beberapa metoda yang sudah digulirkan seperti yang diungkapkan Kanage dan Adiyoso (2012) dimana pendekatan pendidikan kebencanaan dengan memasukan substansi kebencanaan terhadap mata pelajaran dan membuat mata ajaran tersendiri mengenai substansi kebencanaan. Penerapan kurikulum sudah banyak negara yang mengembangkan kurikulum seperti yang di kemukakan (Sinha, Mahendale, Kumar Singh, dan Hegde, 2007), akantetapi yang perlu ditekankan adalah secara substansial disesuaikan dengan situasi dan kondisi di lingkungan masing masing. sejalan dengan yang dikemukakan (Muttarak dan Pothisiri, 2012) faktor mengenai Risk Perception dan self awerenes perlu dikaji sebelum menerapkan program sehingga strategi pembelajaran yang dilakukan dapat tepat sasaran. Penelitian yang dilakukan terhadap 563 responden dari kalangan rumah tangga dengan usia 15 tahun keatas yang dilakukan di daerah rentang bencana di Phang Nga Province Thailand, didapatkan hasil 0.47 yang menunjukan keterkaitan antara pendidikan dengan peningkatan kemampuan individu dalam bencana.

Pendekatan yang coba dilakukan yaitu dengan menggunakan langkah langkah perencanaan kontinjensi yang memiliki 4 tahapan yang di kemukakan oleh Inter-
Agency Standing Committee (IASC) dalam Vidiarina (2010). diantaranya: mempersiapkan dan menyelenggarakan proses perencanaan kontinjensi, melakukan analisis bahaya dan risiko, pengembangan scenario, menentukan tujuan dan strategi tanggap darurat, serta melakukan upaya kesiapsiagaan dengan membuat rencana tindak lanjut yang dapat mereka lakukan dilingkungannya.

Perencanaan kontinjensi biasa dilakukan untuk menyusun langkah strategi penanggulangan bencana berdasarkan potensi ancaman yang telah dilakukan penilaian analisis resiko sebelumnya. Pada penelitian ini langkah-langkah perencanaan kontinjensi ini digunakan kedalam pelaksanaan pemberdayaan masyarakat melalui pelatihan yang di harapkan dapat mengubah kesadaran masyarakat akan ancaman yang ada di daerahnya masing-masing. Pelatihan ini dibagi 3 bagian utama agar dapat berjalan secara sistematis dimana bagian ke-1 dilakukan Introducing dan exploring mengenai persepsi terhadap resiko bencana, kewaspadaan mereka terhadap ancaman bencana, dan kecemasan mereka terhadap ancaman bencana; bagian ke-2 Penguatan, Application, dan reflection dengan melakukan pengkayaan materi, demonstrasi sampai simulasi; bagian ke-3 yaitu bagian lanjutan dengan upaya menyusun rencana tindak lanjut.

Tahapan perencanaan kontinjensi tersebut sejalan dengan beberapa penelitian tentang model pendidikan berbasis lingkungan dalam merubah sikap dan perilaku. Pendekatan ini memungkinkan individu lebih memahami mengenai berbagai potensi dampak umum yang mungkin terjadi dilingkungannya (McGuire, 2015). Selain itu pendekatan ini sangat efektif digunakan untuk masyarakat awam karena sumber pengetahuan mengenai ancaman kematian akibat bencana berasal dari lingkungan yang sehari-hari mereka temui. Dalam penelitian ini lingkungan yang digunakan penelitian 
adalah daerah rawan bencana yaitu di kecamatan Samarang dan Kecamatan Bayongbong Kabupaten Garut. Potensi bencana di daerah tersebut diantaranya longsor, gempa, erupsi gunung Papandayan, serta banjir bandang (BPBD-Provinsi Jabar. 2012). Dalam penelitian ini diwakili oleh 4 sekolah dari dua Kecamatan tersebut yang berada di zona merah diantaranya SMK AlIstiqomah dengan jumlah responden sebanyak 4 (12.10\%), SMK Qurota'ayun sebanyak 10 responden $(30.30 \%)$, SMK Al-Amin sebanyak 9 responden $(27.30 \%)$, dan SMK Mutiara Bangsa sebanyak 10 responden (30.30\%), sehingga proses pemberdayaan melalui pendekatan perencanaan kontinjensi ini efektif dilakukan dalam mengubah faktorfaktor elemnter dari upaya kesiapsiagaan.

Sejauh ini belum ditemukan penelitian yang menggali pengaruh dari perencanaan kontinjensi yang diterapkan kedalam metode pembelajaran untuk masyarakat dalam upaya meningkatkan kesiapsiagaan. Selama ini perencanaan kontinjensi dilakukan dengan baik dalam perumusan rencana pengurangan resiko bencana yang dikoordinir oleh BNPB atau BPBD dengan membentuk berbagai kelompok kerja dan perwakilan masyarakat Vidiarina (2010). Sehingga pada penelitian ini dapat dilihat jika perencanaan kontinjensi ini diterapkan di masyarakat yang merupakan elemen paling bawah sekaligus yang paling terkena dampak bencana.selain itu langkahlangkah perencanaan kontinjensi ini dapat menunjang sesuai dengan teori perubahan prilaku sehingga timbulnya kesadaran masyarakat (McGuire. 2015).

Tumbuhnya kesadaran remaja untuk melakukan kesiapsiagaan terhadap ancaman kematian akibat bencana atau kegawatdaruratan dapat menunjang upaya penanggulangan gawat darurat terpadu, selain itu remaja yang memiliki kemampuan dan kesadaran dapat dilibatkan dalam melakukan pertolongan sebagai first responder, sehingga waktu respon korban dapat efektif. Selain itu keterlibatan kelompok potensial remaja yang terpapar dunia komunikasi dapat menunjang efektifitas dari sistem informasi geografis (SIG) yang dikembangkan Universitas padjadjaran yang diberi nama sistem informasi bencana padjadjaran (SIMBARAN) (Emaliyawati, Prawesti, Yosep, Ibrahim, 2016). Sehingga upaya mitigasi dan kesiapsiagaan dalam proses penanggulangan ancaman kematian akibat bencana dapat berjalan efektif.

\section{SIMPULAN}

Hasil penelitian ini dapat disimpulkan bahwa pemberdayaan (empowering) pada kelompok remaja akhir melalui pendekatan perencanaan kontinjensi dapat meningkatkan upaya kesiapsiagaan dalam menghadapi ancaman kematian akibat bencana di Kabupaten Garut. Peningkatan upaya kesiapsiagaan tersebut dilandasi dari peningkatan faktor prekursor, intention formation, dan preparation planing. Sehingga metode dengan pendekatan ini dapat menjadi salah satu upaya yang dapat dilakukan dalam meningkatkan kapasitas remaja, sehingga kedepan dapat terbentuk kelompok baru di masyarakat yang memiliki kesadaran dari diri sendiri untuk senantiasa siapsiaga. Selain itu dengan proses pembinaan berkelanjutan maka kelompok ini dapat diberdayakan dalam melakukan proses pendampingan dimasyarakat dalam meningkatkan kemampuan masyarakat.

\section{SARAN}

Hasil penelitian menunjukan bahwa pemberdayaan remaja dengan pendekatan perencanaan kontinjensi dapat meningkatkan kesiapsiagaan terhadap ancaman kematian akibat bencana. oleh karena itu perlu diterapkan bentuk pemberdayaan melalui perencanaan kontinjensi dalam bentuk pemebelajaran bencana dalam rangka meningkatkan kesiapsiagaan remaja baik secara formal maupun informal. Selain itu perlu dilakukan penelitian berkelanjutan untuk menilai sejauhmana kesiapsiagaan 
remaja dan penerapannya di masyarakat pasca intervensi.

\section{DAFTAR PUSTAKA}

Arimastuti, A. 2011. Tahapan proses komunikasi fasilitator dalam sosialisasi penguragan resiko bencana, Jurnal penanggulangan bencana, 2011, vol 2, No 2, hlm 15-23.

American Association of Critical-Care Nurses. 2015. Scope and Standards For Acute and Critical Care Nursing Practice. ISBN 1-929209-22-3. Ed: Linda Bell, RN, MSN. AACN Critical Care Publication. Columbia :USA

Badan Nasional Penanggulangan Bencana (BNPB). 2016. Data Bencana: Statistik. Diakses pada tanggal 19 September 2016 dari Data dan Informasi Bencana Indonesia BNPB melalui http://dibi.bnpb.go.id/data-

bencana/statistik.

Badan Penanggulangan Bencana Daerah (BPBD) Provinsi Jawa Barat. 2011. Rencana Kontinjensi Ancaman Erupsi Gunung Papandayan. Unpublished BPBD Provinsi JABAR.

Badan Penanggulangan Bencana Daerah (BPBD) Provinsi Jawa Barat. 2016. Laporan Penanganan Bencana Banjir Bandang Kabupaten Garut. 26 September 2016. BPBD Provinsi JABAR

Dodon. 2013. Indikator dan Perilaku Kesiapsiagaan Msyarakat di Permukiman Padat Penduduk dalam Antisipasi Berbagai Fase Bencana Banjir. Jurnal Perencanaan Wilayah dan Kota, Vol. 24 No. 2, Agustus 2013, hlm. 125 - 140 .

Emaliyawati, Prawesti, Yosep, Ibrahim, 2016. Manajemen Mitigasi Bencana dengan Teknologi Informasi di Kabupaten Ciamis. Jurnal Keperawan Padjdjaran. Vol 4, No. 1, 2016.

Grizzell, J. (2007). Behavior Change theories and Models. retrieved January 28,
2007, from http://www.csupomona. edu/ jvgrizzell/best_practices/bctheory .html.

Hair et.al. 2010. Multivariate Data Analysis, Seventh Edition. Pearson Prentice Hall Indriyati dan Antaria. 2013. Pemberdayaan Masyarakat Korban Bencana Di Daerah pengungsian Dalam Rangka Pencegahan KLB (Kejadian Luar Biasa) Penyakit Menular. Jurnal Ilmiah Kesehatan, Mei 2013, 5 (2), hlm 31134.

Kanege. H dan Adiyoso.W. 2012. The effect of different disaster education programs on tsunami preparedness among schoolchildren in Aceh, Indonesia. Disaster Mitigation of Cultural Heritage and Historic Cities, Vol. 6 July. Page 165-172.

Mahmud. 2011. Metode Penelitian Pendidikan. Bandung: Pustaka Setia.

Martin.W, Martin. I, dan Kent. 2009. The Role of Risk Perceptions in The Risk Mitigation Process: The Case of Wildfire in High Risk Communities. Journal of Environmental Management. No. 91 (2009), hlm 489498.

McGuire, M. 2015. Environmental Education and Behavioral Change: An IdentityBased Environmental Education Model. International Journal of Environmental \& Science Education, 2015, 10(5), hlm, 695-715.

Muttarak, R.,\& Pothisiri, W. 2013. The role of education on disaster preparedness: case study of 2012 Indian Ocean earthquakes on Thailand's Andaman Coast. Ecology and Society 18(4): 51. http://dx.doi.org/10.5751/ES-06101180451

Oktaviani. D, 2012. Resiliensi Remaja Aceh yang Mengalami Bencana Tsunami. Universitas Indonesia

Paton et. al. 2005. Developing a model to predict the adoption of natural hazard risk reduction andpreparatory 
adjustments. EQC Research Project No. 01-479

Paton,D. 2007. Community Resilience: Integrating Hazard Management and Community Engagement. Schoolof Psychology. Australia: University of Tasmania.

Pusat Data dan Informasi Kementrian Kesehatan RI. 2015. Situasi Kesehatan Reproduksi Remaja. Dalam (InfoDATIN) 29 Juni 2015 Dalam Rangka Hari Kesehatan Nasional (HKN), ISSN 2442-7659 (Paper). Jakarta: Kemkes R.I.

Pusat Penanggulangan Krisis (PPK) Kesehatan. 2013. Buku Tinjauan Penanggulangan Krisis Kesehatan tahun 2012. Jakarta:Kementrian Kesehatan R.I.

Pusat Penanggulangan Krisis (PPK) Kesehatan. 2015. Pedoman Pemberdayaan Masyarakat dalam Penanggulangan Krisis Kesehatan.. Jakarta:Kementrian Kesehatan R.I

Raharjo, W. 2010. Analisis Penanggulangan Bencana Berbasis Perspektif Cultural Theory. Jurnal Penanggulangan Bencana. ISSN: 2087 636X, Volume 4 Nomor 1, Juni 2013. Hlm 1-12.

Sinha. R, Mahendale.V, Kumar Singh.Y, dan Hegde.G. 2007. School Education For disaster Reduction. Jurnal Disaster Education. National Graduate Institute for Policy Studies (GRIPS). Page 1-27

Sugiyono. (2010). Metode Penelitian Kuantitatif Kualitatif \& RND. Bandung: Alfabeta.

Triyanto,Setiyani, dan Wulansari, 2014. Pengaruh Dukungan Keluarga dalam Meningkatkan Perilaku Adaptif Remaja Pubertas. Jurnal Keperawatan Padjadjaran.Vol 2, No. 1, 2014.

U.S. Departement of Health and Human Sevices. 2011. Public health emergency response guide for state, local, and tribal Public HealtH directors. Version 2.0, April 2011.

Undang-undang Nomor 24 Tahun 2007 Tentang Penanggulangan Bencana. 2007. BNPB

Vidiarina. 2010. Perencanaan Kontinjensi Tinjauan tentang beberapa Pedoman Perencanaan dan Rencana Kontinjensi. Dokumen Kerja No. 26 Baseline Study. GTZ-International Services: Jakarta

Zuldafrial. 2010. Perkembangan Nilai,, Moral, dan Sikap Remaja. Diakses online pada https://jurnaliainpontianak.or.id pada tanggal 20 Maret 2017. Hal 29-48 